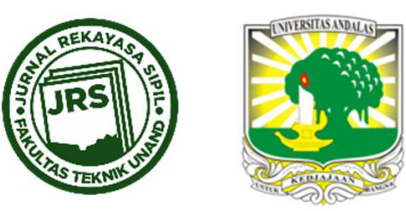

\title{
ANALISIS FAKTOR PENYEBAB COST OVERRUNS PADA PROYEK KONSTRUKSI PEMBANGUNAN RUMAH DAN RUKO DI KOTA BANDUNG DAN CIMAHI
}

\author{
ALVIN PRAYOGO SOEKIMAN ${ }^{1}$, ANTON SOEKIMAN ${ }^{1 *}$ \\ ${ }^{1}$ Konsentrasi Manajemen Konstruksi, Magister Teknik Sipil, Universitas Katolik Parahyangan, Bandung, Indonesia \\ ${ }^{2}$ Jurusan Teknik Sipil, Fakultas Teknik, Universitas Katolik Parahyangan, Bandung, Indonesia \\ *Corresponding author: $\bowtie$ soekiman@unpar.ac.id
}

Naskah diterima : 29 Agustus 2020. Disetujui: 21 Januari 2021

\begin{abstract}
ABSTRAK
Dalam pelaksanaan pembangunan proyek konstruksi sering terjadi pengeluaran biaya yang melebih anggaran yang telah direncanakan. Kelebihan biaya yang dikenal dengan cost overruns ini akan membebani pihak pelaksana jasa konstruksi terutama untuk kontrak Lumpsum Fixed Price. Penelitian ini difokuskan pada proyek konstruksi rumah tinggal dan rumah toko (ruko) dengan kontrak lumpsum di Indonesia dengan ruang lingkup penelitian di Kota Bandung dan Cimahi. Penelitian ini mengidentifikasi faktor-faktor yang dapat menyebabkan terjadinya cost overruns dalam pelaksanaan proyek konstruksi rumah tinggal kecil-menengah dan rumah toko serta memodelkan hubungan sebab akibat dari faktor-faktor yang dapat menyebabkan terjadinya cost overruns tersebut dengan metode analisis jalur atau sering dikenal dengan metode Path Analysis. Data dikumpulkan melalui kuesioner dengan sasaran utama sebagai respondennya adalah para kontraktor atau minimal berada dijajaran Project Manager dalam sebuah proyek. Hasil penelitian menghasilkan bahwa faktor terkait kelengkapan desain merupakan faktor utama dalam terjadinya cost overruns sehingga semakin lengkap desain awal perencanaan maka semakin kecil kemungkinan terjadinya cost overruns Sementara jalur yang memiliki pengaruh paling dominan yaitu: cost overruns dipengaruhi oleh faktor terkait kinerja hasil pekerjaan, yang sebelumnya dipengaruhi oleh faktor terkait tenaga kerja, yang sebelumnya oleh faktor terkait kondisi hukum, sosial dan ekonomi, yang sebelumnya oleh faktor terkait kelengkapan desain. Sehingga dapat dilihat bahwa sumber permasalahan utama dari jalur yang paling dominan adalah faktor-faktor terkait kelengkapan desain.
\end{abstract}

Kata kunci : cost overruns; kelengkapan desain; proyek konstruksi rumah; analisis jalur

\section{PENDAHULUAN}

Dunia konstruksi berkembang sangat cepat guna memenuhi kebutuhan hidup orang banyak. Dari dunia konstruksi ini dihasilkan berbagai proyek dari rumah tinggal, ruko hingga gedung-gedung tinggi, jembatan, dan bangunan lain. Proyek tersebut tercipta berdasarkan kebutuhan dari pengguna akhir yang menginginkan sebuah bangunan gedung atau

DOI : https://doi.org/10.25077/jrs.17.1.13-23.2021

Attribution-NonCommercial 4.0 International. Some rights reserved 
infrastruktur yang sesuai dengan peruntukan dan fungsi yang akan diterapkan kepada bangunan tersebut. Beberapa contoh sumber permasalahan yang sering terjadi dalam pelaksanaan proyek konstruksi adalah kinerja pelaksana proyek konstruksi, masalah keuangan, masalah-masalah manajerial, tidak tersedianya sumber daya, kondisi eksternal, dan lain sebagainya (Febrian, 2017). Dari semua permasalahan yang terjadi, ada satu permasalahan yang umumnya dialami oleh semua pihak yaitu permasalahan biaya. Pada umumnya biaya konstruksi disepakati sebelum proyek berjalan. Setelah terjadi kesepakatan harga beserta dengan spesifikasi yang sesuai ditambah dengan beberapa rincian lainnya maka proyek tersebut dapat dikerjakan. Dalam prosesnya biaya ini terus dipantau guna menjaga agar biaya yang telah dianggarkan tidak melebihi rencana biaya yang telah disepakati.

Namun dengan berjalannya proyek, pada umumnya ada saja permasalahan atau kejadian yang tidak terduga yang terjadi sehingga diperlukan penyesuaian atas biaya proyek tersebut. Whatever action we take, whatever we do or fail to do, there are costs involved (Heinz and Wesney in Westney, 1997), Setiap keputusan dari permasalahan yang dialami akan menimbulkan sejumlah biaya yang harus dikeluarkan. Permasalahan ini memiliki efek yang berbeda terhadap objek yang berbeda seperti pada bangunan rumah dan ruko. Perbedaan ini ada pada karakteristik proyek rumah dan ruko yang ada di Indonesia. Pada umumnya proyek ini memiliki karakterikstik sebagai berikut:

1. Kontrak lumpsum dimana khusus untuk proyek dengan kontrak lumpsum, masalah cost overruns ini akan menjadi beban dari pihak kontraktor;

2. Pada umumnya pembangunan proyek ini memberlakukan sistem design-bulid sehingga kontraktor bertanggung jawab terhadap perencanaan dan pembangunannya;

3. Umumnya kontraktor menggunakan cukup banyak jasa sub-kontraktor lain dengan spesifikasi keahlian yang khusus.

4. Banyak kontraktor yang mengerjakan proyek rumah dan ruko merupakan kontraktor kecil dengan modal yang terbatas. Sehingga ketika mereka mengalami cost overruns maka keberlangsungan mereka sebagai kontraktor akan terganggu.

Penelitian terkait cost overruns telah banyak dilakukan oleh peneliti baik di dalam maupun di luar negeri. Namun pada umumnya para peneliti mengkajinya pada lingkup umum atau pada proyek skala besar saja. Ada anggapan bahwa faktor penyebab terjadinya cost overruns bisa berbeda tergantung kepada jenis proyek, kompleksitas proyek, nilai proyek, atau lokasi proyek. Oleh karena itu menarik untuk diteliti faktor-faktor penyebab cost overruns secara lebih rinci pada objek dan lokasi tertentu.

Pada penelitian ini lingkup proyek yang akan dikaji adalah proyek rumah tinggal kecilmenengah dan ruko dengan kontrak lumpsum dengan lokasi objek studi Bandung dan Cimahi yang merupakan salah satu kota dengan jumlah penduduk yang cukup padat di Indonesia. Kedua kota ini dipilih dikarenakan Bandung sebagai salah satu kota yang memiliki jumlah penduduk yang cukup padat di Indonesia dan diikuti oleh kebutuhan akan rumah dan ruko yang cukup besar

Sehubungan dengan seringnya terjadi cost overrun dalam pelaksanaan sebuah proyek maka perlu dikaji faktor-faktor apa saja yang mempengaruhi biaya proyek sehingga dapat melebihi anggaran yang telah direncanakan serta bagaimana keterkaitan faktor-faktor tersebut terhadap tejadinya cost overrun dalam pelaksanaan proyek. 
Proyek merupakan sebuah kegiatan yang dilakukan bersamaan dengan kegiatan organisasi dan membutuhkan sinergi dengan perusahaan. Sebuah proyek dapat didefinisikan sebagai: " A project is a complex, nonroutine, one-time effort limited by time, budget, resources, and performance spesifications, designed to meet customer needs" (Gray \& Larson, 2000). Industri konstruksi telah dianggap sebagai industri dinamis yang selalu mengadapi ketidakpastian dalam penganggarannya, prosesnya dan teknologinya (Chan et al., 2004). Ketidakpastian, tingkat kerumitan proyek dan peningkatan pemangku kepentingan membuat pelaksanaan manajemen biaya yang sangat sulit dalam proyek konstruksi. Hal tersebut mengakibatkan terjadinya keterlambatan dan cost overrun dalam proyek (Doloi, 2013).

"The nature and causes of time overruns and their impact on project costs also vary between developing and developed countries" (Shebob et al., 2012). Untuk dapat memberikan penilaian yang akurat dan tepat sasaran maka perlu dilakukan indentifikasi untuk mengenali faktor-faktor yang mempengaruhi terjadinya cost overrun. "Keeping construction projects within estimated costs and schedules requires sound strategies, good practices and careful judgment" (Famiyeh et al., 2017).

Beberapa peneliti terdahulu telah melakukan penelitian untuk mengidentifikasi faktorfaktor yang mempengaruhi cost overrun. Pada setiap penelitian yang dilakukan terdapat banyak faktor yang mirip atau bahkan sama namun dari setiap peneliti juga memiliki pendapat masing-masing sehingga muncul juga beberapa perbedaan pada masing-masing hasil penelitian. Dalam penelitian ini, dari berbagai faktor yang telah ditemukan dirangkum dan disesuaikan dengan batasan dan objek penelitian ini.

\section{METODOLOGI PENELITIAN}

Untuk menjawab tujuan penelitian ini, yakni: mengidentifikasi faktor-faktor yang mempengaruhi cost overrun serta memodelkan hubungan antar faktor-fakotr tersebut, pengumpulan data dilakukan dengan menggunakan metode kuesioner yang dibagikan kepada kontraktor yang pernah mengerjakan proyek konstruksi rumah tinggal dan rumah toko (ruko) di Kota Bandung dan Cimahi.

Variabel yang digunakan dalam penelitian ini merupakan hasil gabungan dari berbagai literatur yang kemudian disaring dan disesuaikan dengan kondisi di Kota Bandung dan Cimahi. Faktor-faktor tersebut ditampilkan pada Tabel $\mathbf{1}$.

Tabel 1. Variabel Penelitian: Faktor Penyebab Cost Overrun

\begin{tabular}{|c|c|c|}
\hline No. & Faktor penyebab Cost Overrun & Referensi \\
\hline \multirow[t]{5}{*}{1.} & Faktor-faktor terkait kelengkapan desain (VAR1) & \\
\hline & $\begin{array}{l}\text { - Lingkup yang tidak didefinisikan dengan } \\
\text { baik }\end{array}$ & $\begin{array}{l}\text { (Doloi, 2013) (Famiyeh et al., 2017) (Azhar } \\
\text { et al., 2008) (Enshassi et al., 2009) } \\
\text { (Kaming et al., 1997) (Memon et al., 2012) } \\
\text { (Memon \& Rahman, 2013) dan (Wanjari } \\
\text { \& Dobariya, 2016) }\end{array}$ \\
\hline & $\begin{array}{l}\text { - Perubahan spesifikasi yang ditentukan } \\
\text { oleh pemilik }\end{array}$ & $\begin{array}{l}\text { (Famiyeh et al., 2017) (Doloi, 2013) } \\
\text { (Wanjari \& Dobariya, 2016) dan (Memon } \\
\text { \& Rahman, 2013) }\end{array}$ \\
\hline & - Variasi (perubahan desain / kerja ekstra) & $\begin{array}{l}\text { (Famiyeh et al., 2017) (Doloi, 2013) } \\
\text { (Wanjari \& Dobariya, 2016) dan (Memon } \\
\text { \& Rahman, 2013) }\end{array}$ \\
\hline & - Komunikasi dan koordinasi yang buruk & $\begin{array}{l}\text { (Famiyeh et al., 2017) (Doloi, 2013) (Azhar } \\
\text { et al., 2008) (Enshassi et al., 2009) }\end{array}$ \\
\hline
\end{tabular}


Analisis Faktor Penyebab Cost Overruns Pada Proyek Konstruksi Pembangunan Rumah Dan Ruko Di Kota Bandung Dan Cimahi

\begin{tabular}{|c|c|c|}
\hline No. & Faktor penyebab Cost Overrun & Referensi \\
\hline & & $\begin{array}{l}\text { (Wanjari \& Dobariya, 2016) dan (Memon } \\
\text { \& Rahman, 2013) }\end{array}$ \\
\hline \multirow[t]{4}{*}{2.} & Faktor-faktor terkait klien (VAR2) & \\
\hline & - Masalah Keuangan & $\begin{array}{l}\text { (Memon \& Rahman, 2013) (Le-Hoai et al., } \\
\text { 2008) }\end{array}$ \\
\hline & $\begin{array}{lll}\text { Keterlambatan } & \text { pembayaran } \\
\text { kontraktor }\end{array}$ & $\begin{array}{l}\text { (Memon \& Rahman, 2013) (Wanjari \& } \\
\text { Dobariya, 2016) (Doloi, 2013) (Kaming et } \\
\text { al., 1997) (Famiyeh et al., 2017) }\end{array}$ \\
\hline & - Arus komunikasi yang lambat & $\begin{array}{l}\text { (Enshassi et al., 2009) (Memon } \& \\
\text { Rahman, 2013) (Le-Hoai et al., 2008) }\end{array}$ \\
\hline \multirow[t]{4}{*}{3.} & Faktor-faktor terkait kemampuan kontraktor (V & AR3) \\
\hline & - Kekurangan peralatan dan alat di lokasi & (Famiyeh et al., 2017) (Doloi, 2013) \\
\hline & $\begin{array}{l}\text { - Pengalaman kontraktor yang tidak } \\
\text { memadai }\end{array}$ & $\begin{array}{l}\text { (Famiyeh et al., 2017) (Doloi, 2013) } \\
\text { (Enshassi et al., 2009) (Kaming et al., } \\
\text { 1997) (Memon et al., 2012) }\end{array}$ \\
\hline & - $\quad$ Pengendalian internal proyek & $\begin{array}{l}\text { (Doloi, 2013) (Famiyeh et al., 2017) (Le- } \\
\text { Hoai et al., 2008) (Azhar et al., 2008) } \\
\text { (Kaming et al., 1997) (Memon et al., 2012) } \\
\text { (Memon \& Rahman, 2013) (Wanjari \& } \\
\text { Dobariya, 2016) }\end{array}$ \\
\hline \multirow[t]{2}{*}{4.} & Faktor-faktor terkait kemampuan subkontraktol & (VAR4) \\
\hline & $\begin{array}{l}\text { Subkontraktor yang kurang pengalaman, } \\
\text { dll }\end{array}$ & $\begin{array}{l}\text { (Famiyeh et al., 2017) (Doloi, 2013) (Le- } \\
\text { Hoai et al., 2008) (Omoregie \& Radford, } \\
\text { 2006) (Memon \& Rahman, 2013) }\end{array}$ \\
\hline \multirow[t]{4}{*}{5.} & Faktor-faktor terkait tenaga kerja (VAR5) & \\
\hline & - Ketepatan jumlah komposisi tenaga kerja & $\begin{array}{l}\text { (Famiyeh et al., 2017) (Doloi, 2013) (Le- } \\
\text { Hoai et al., 2008) (Memon \& Rahman, } \\
\text { 2013) }\end{array}$ \\
\hline & $\begin{array}{l}\text { Keterkaitan upah tenaga kerja dengan } \\
\text { produktifitas }\end{array}$ & $\begin{array}{l}\text { (Memon \& Rahman, 2013) (Azhar et al., } \\
\text { 2008) (Kaming et al., 1997) }\end{array}$ \\
\hline & - Tingkat kehadiran tenaga kerja & $\begin{array}{l}\text { (Omoregie \& Radford, 2006) (Memon \& } \\
\text { Rahman, 2013) (Azhar et al., 2008) } \\
\text { (Memon et al., 2012) }\end{array}$ \\
\hline \multirow[t]{3}{*}{6.} & Faktor-faktor terkait kinerja hasil pekerjaan $(\mathrm{V}$ & R6) \\
\hline & - Keterlambatan penyelesaian pekerjaan & $\begin{array}{l}\text { (Azhar et al., 2008) (Enshassi et al., 2009) } \\
\text { (Kaming et al., 1997) (Memon et al., 2012) } \\
\text { (Doloi, 2013) (Famiyeh et al., 2017) (Le- } \\
\text { Hoai et al., 2008) (Memon \& Rahman, } \\
\text { 2013). }\end{array}$ \\
\hline & - Ketepatan hasil pekerjaan/ rework & $\begin{array}{l}\text { (Famiyeh et al., 2017) (Doloi, 2013) (Le- } \\
\text { Hoai et al., 2008) (Omoregie \& Radford, } \\
\text { 2006) (Wanjari \& Dobariya, 2016) } \\
\text { (Memon \& Rahman, 2013) }\end{array}$ \\
\hline \multirow[t]{3}{*}{7.} & Faktor-faktor terkait material (VAR7) & \\
\hline & - Peningkatan harga material & $\begin{array}{l}\text { (Famiyeh et al., 2017) (Doloi, 2013) } \\
\text { (Enshassi et al., 2009) (Kaming et al., } \\
\text { 1997) (Memon et al., 2012) (Le-Hoai et al., } \\
\text { 2008) }\end{array}$ \\
\hline & - Ketepatan jumlah material yang datang & $\begin{array}{l}\text { (Memon \& Rahman, 2013) (Enshassi et } \\
\text { al., 2009) (Kaming et al., 1997) (Famiyeh } \\
\text { et al., 2017) (Doloi, 2013) }\end{array}$ \\
\hline
\end{tabular}




\begin{tabular}{|c|c|c|}
\hline No. & Faktor penyebab Cost Overrun & Referensi \\
\hline & - Keterlambatan pengiriman material & $\begin{array}{l}\text { (Famiyeh et al., 2017) (Doloi, 2013) (Le- } \\
\text { Hoai et al., 2008) (Omoregie \& Radford, } \\
\text { 2006) (Memon \& Rahman, 2013) }\end{array}$ \\
\hline & $\begin{array}{ll}\text { - } & \text { Ketepatan penggunaan material sesuai } \\
\text { spesifikasi }\end{array}$ & (Doloi, 2013) \\
\hline & - $\begin{array}{l}\text { Keterlambatan pembayaran kepada } \\
\text { suplier }\end{array}$ & $\begin{array}{l}\text { (Omoregie \& Radford, 2006) (Memon \& } \\
\text { Rahman, 2013) }\end{array}$ \\
\hline \multirow[t]{3}{*}{8.} & Faktor-faktor terkait kondisi alam (VAR8) & \\
\hline & $\begin{array}{l}\text { - Kondisi lokasi yang buruk (lokasi, tanah, } \\
\text { dll.) }\end{array}$ & (Famiyeh et al., 2017) (Doloi, 2013) \\
\hline & - Cuaca yang kurang baik & $\begin{array}{l}\text { (Famiyeh et al., 2017) (Doloi, 2013) } \\
\text { (Wanjari \& Dobariya, 2016) }\end{array}$ \\
\hline \multirow[t]{9}{*}{9.} & Faktor-faktor terkait kondisi hukum, sosial dan & konomi (VAR9) \\
\hline & $\begin{array}{l}\text { - Kondisi ekonomi yang buruk (mata uang, } \\
\text { tingkat inflasi, dll.) }\end{array}$ & $\begin{array}{l}\text { (Famiyeh et al., 2017) (Doloi, 2013) } \\
\text { (Wanjari \& Dobariya, 2016) }\end{array}$ \\
\hline & - $\quad$ Perubahan hukum dan peraturan & (Famiyeh et al., 2017) \\
\hline & - $\quad$ Rendahnya produktivitas & (Doloi, 2013) \\
\hline & - Pemogokan & (Famiyeh et al., 2017) \\
\hline & - Pekerjaan eksternal karena badan publik & (Famiyeh et al., 2017) \\
\hline & - Masalah dengan tetangga & (Famiyeh et al., 2017) \\
\hline & $\begin{array}{ll}\text { Masalah dengan } \\
\text { kemasyarakatan }\end{array}$ & (Wanjari \& Dobariya, 2016) \\
\hline & - Masalah dengan oknum pemerintah & (Wanjari \& Dobariya, 2016) \\
\hline & Faktor terkait kenaikan biaya proyek (VAR10) & \\
\hline & - Kenaikan biaya biaya proyek & \\
\hline
\end{tabular}

Variabel penelitian tersebut dinilai dengan skala likert melalui penyebaran kuesioner kepada para responden yang terkait. Dari hasil kuesioner ini diperoleh 36 respon dengan penyebaran data berdasarkan tingkat pendidikan terakhir sebagai berikut: 0 orang responden memiliki pendidikan terakhir D3, 27 orang responden memiliki pendidikan terakhir Sarjana, 7 orang responden memiliki pendidikan terakhir Magister, 2 orang responden memiliki pendidikan terakhir Doktoral. Dari sisi pengalaman proyek responden tersebar sebagai berikut: 8 orang responden memiliki pengalaman proyek $<5$ tahun, 11 orang responden memiliki pengalaman proyek 5 - 10 tahun, 2 orang responden memiliki pengalaman proyek 10 - 15 tahun, 6 orang responden memiliki pengalaman proyek $15-20$ tahun, 9 orang responden memiliki pengalaman proyek $>20$ tahun. Dari sisi nilai proyek yang pernah dilakukan diperoleh penyebaran data sebagai berikut: 0 orang responden memiliki pengalaman proyek dengan nominal rata-rata $<1$ milyar rupiah, 8 orang responden memiliki pengalaman proyek dengan nominal rata-rata $1-1.5$ milyar rupiah, 17 orang responden memiliki pengalaman proyek dengan nominal rata-rata 1.5 - 2 milyar rupiah, 11 orang responden memiliki pengalaman proyek dengan nominal rata-rata $>2$ milyar rupiah.

Berdasarkan faktor-faktor yang telah ditentukan maka dibuat hipotesa diagram jalur awal yang kemudian akan dianalisis lebih lanjut seperti pada Gambar 1.

Setelah seluruh data kuesioner dikumpulkan, selanjutnya dilakukan analisa terhadap data tersebut. Analisa yang akan dilakukan berupa analisa ranking yang kemudian dilanjutkan dengan analisa hubungan jalur menggunakan metoda Path Analysis. Pada metode ini, data rata-rata variabel hasil kuesioner yang telah diperoleh kemudian di analisa menggunakan LISREL 8.8. Kemudian dari diagram jalur yang muncul kemudian dianalisa dan jika 
ditemukan hubungan yang negatif maka diperbaiki modelnya hingga semua nilai hubungan menjadi positif.

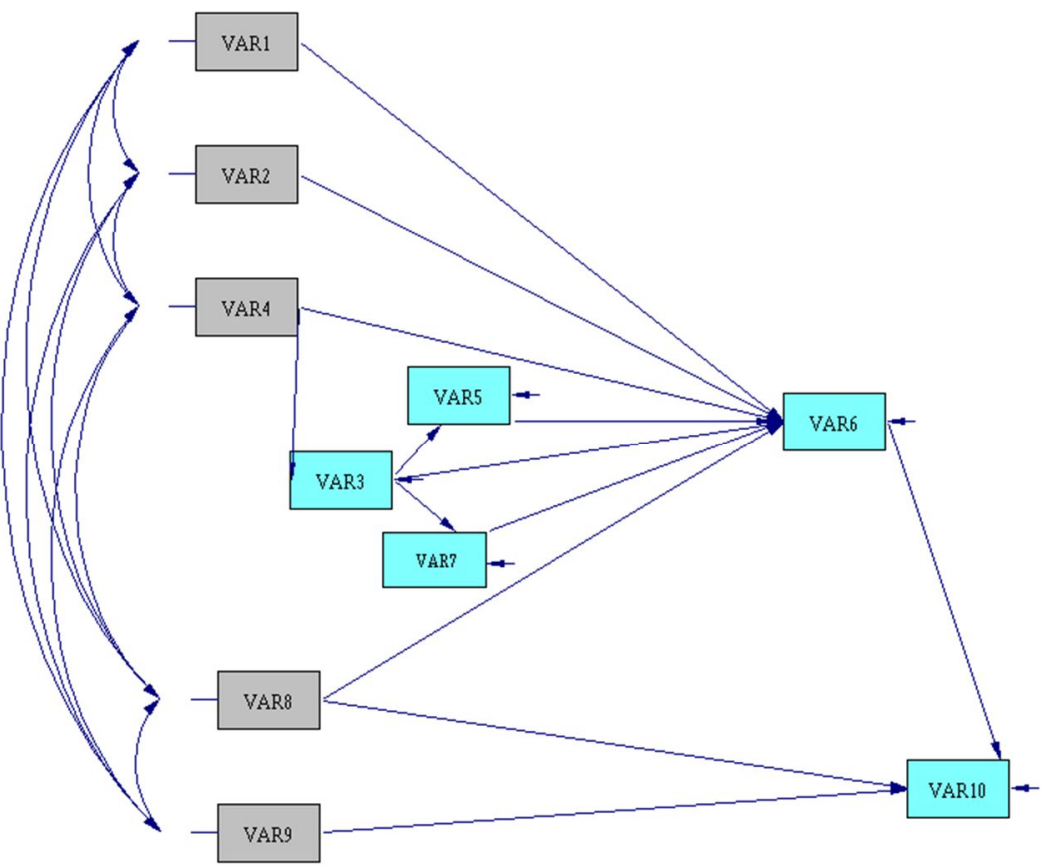

Gambar 1. Hipotesis awal penelitian

\section{ANALISIS DAN PEMBAHASAN}

Menurut Azwar (2003, dalam Soekiman \& Syamsuduha, 2011) bahwa para ahli menetapkan patokan besaran koefisien korelasi item total dikoreksi sebesar 0.33 dengan tingkat error sebesar $5 \%$ sebagai batas minimal valid tidaknya sebuah item. Dengan menggunakan SPSS 20 maka validitas dapat dilihat pada Tabel 2 terlihat bahwa korelasi faktor-faktor yang ada cukup baik.

Tabel 2. Uji Validitas

\begin{tabular}{|c|c|c|c|}
\hline Variable & Mean & $\begin{array}{c}\text { Std. } \\
\text { Deviation }\end{array}$ & $\begin{array}{l}\text { Corrected item - } \\
\text { total correlation }\end{array}$ \\
\hline Faktor-faktor terkait kelengkapan desain (VAR1) & 4,1667 & 0,64087 & 0.670 \\
\hline Faktor-faktor terkait klien (VAR2) & 4,0833 & 0,67788 & 0.670 \\
\hline $\begin{array}{l}\begin{array}{l}\text { Faktor-faktor terkait kemampuan kontraktor } \\
\text { (VAR3) }\end{array} \\
\end{array}$ & 3,9861 & 0,54098 & 0.736 \\
\hline $\begin{array}{l}\text { Faktor-faktor terkait kemampuan subkontraktor } \\
\text { (VAR4) }\end{array}$ & 4,0833 & 0,64918 & 0.605 \\
\hline Faktor-faktor terkait tenaga kerja (VAR5) & 4,0556 & 0,72812 & 0.923 \\
\hline $\begin{array}{l}\begin{array}{l}\text { Faktor-faktor terkait kinerja hasil pekerjaan } \\
\text { (VAR6) }\end{array} \\
\end{array}$ & 4,0694 & 0,54098 & 0.655 \\
\hline Faktor-faktor terkait material (VAR7) & 3,9389 & 0,46061 & 0.490 \\
\hline Faktor-faktor terkait kondisi alam (VAR8) & 3,6528 & 0,93975 & 0.480 \\
\hline $\begin{array}{l}\text { Faktor-faktor terkait kondisi hukum, sosial dan } \\
\text { ekonomi (VAR9) }\end{array}$ & 3,0660 & 0,85799 & 0.857 \\
\hline Faktor terkait cost overrun (VAR10) & 4,1667 & 0,60945 & 0.736 \\
\hline
\end{tabular}


Untuk menguji realibilitas menurut Hair, et. Al (1998, dalam Soekiman \& Syamsuduha, 2011) dapat digunakan koefisien alpha cronbach, dimana data akan dianggap reliabel jika koefisiennya lebih besar atau sama dengan 0,7. Dengan menggunakan SPSS 20 maka dapat dilihat pada tabel 2 koefisien yang dihasilnya berada di angka 0.725 sehingga faktor-faktor yang ada di dalam penelitian ini dianggap cukup reliabel.

Berdasarkan data yang ada, maka dapat diperoleh rerata (mean) untuk menggambarkan tingkat pengaruh dari variabel yang ada yang ditampilkan pada Tabel 3 .

Tabel 3. Ranking dari seluruh variabel

\begin{tabular}{llll}
\hline \multicolumn{1}{c}{ Variable } & Mean & $\begin{array}{c}\text { Std. } \\
\text { Deviation }\end{array}$ & Ranking \\
\hline $\begin{array}{l}\text { Faktor-faktor terkait kelengkapan desain } \\
\text { (VAR1) }\end{array}$ & 4,1667 & 0,64087 & 1 \\
\hline Faktor-faktor terkait tenaga kerja (VAR5) & 4,1204 & 0,72812 & 2 \\
\hline $\begin{array}{l}\text { Faktor-faktor terkait kemampuan kontraktor } \\
\text { (VAR3) }\end{array}$ & 4.1111 & 0,54098 & 3 \\
\hline Faktor-faktor terkait klien (VAR2) & 4,0833 & 0,67788 & 4 \\
\hline $\begin{array}{l}\text { Faktor-faktor terkait kinerja hasil pekerjaan } \\
\text { (VAR6) }\end{array}$ & 4,0694 & 0,54098 & 5 \\
\hline $\begin{array}{l}\text { Faktor-faktor terkait kemampuan } \\
\text { subkontraktor (VAR4) }\end{array}$ & 4,0600 & 0,64918 & 6 \\
\hline Faktor-faktor terkait material VAR7) & 3,9389 & 0,46061 & 7 \\
\hline Faktor-faktor terkait kondisi alam(VAR8) & 3,6528 & 0,93975 & 8 \\
\hline $\begin{array}{l}\text { Faktor-faktor terkait kondisi hukum, sosial } \\
\text { dan ekonomi (VAR9) }\end{array}$ & 3,0660 & 0,85799 & 9 \\
\hline
\end{tabular}

Berdasarkan hasil hipotesis yang telah dibuat sebelumnya maka dilakukan perbaikan dan estimasi ulang sehingga mendapatkan hasil seperti pada Gambar 2 dan Gambar 3.

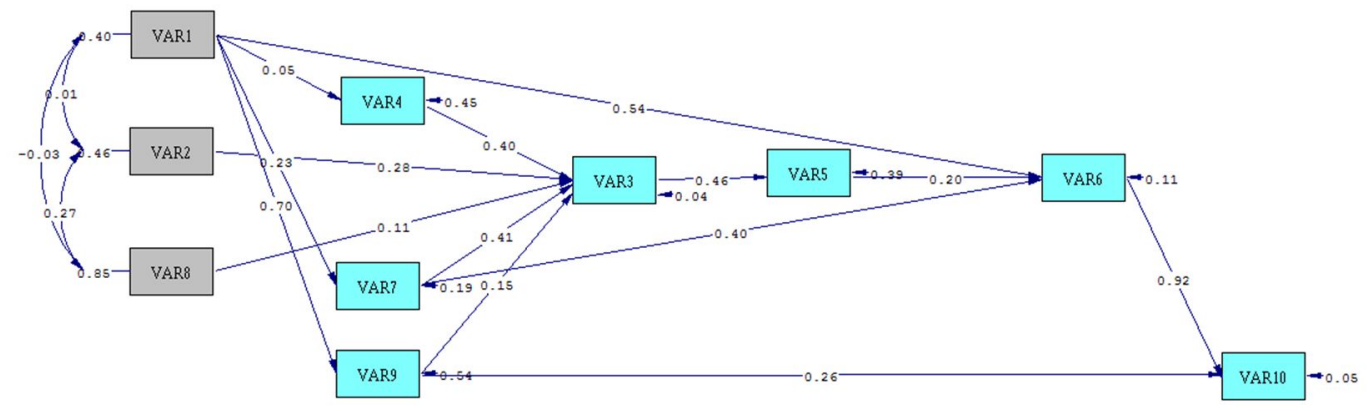

Gambar 2. Perbaikan diagram estimasi jalur

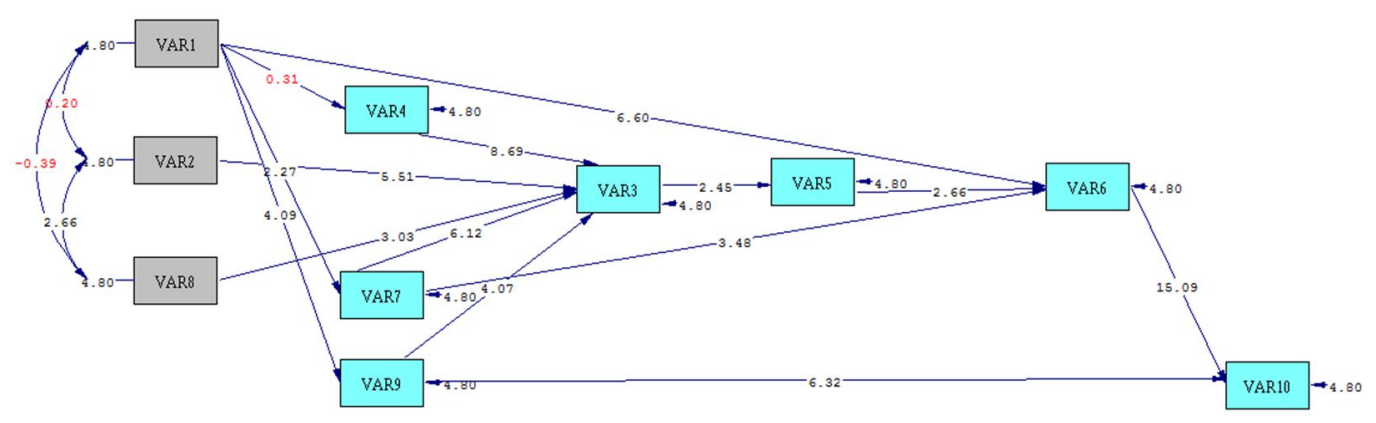

Gambar 3. Perbaikan diagram T-value 
Dari hasil tersebut menunjukkan adanya perubahan model, dimana yang sebelumnya Faktor-faktor terkait kinerja hasil pekerjaan (VAR6) dipengaruhi oleh Faktor-faktor terkait kelengkapan desain (VAR1), Faktor-faktor terkait klien (VAR2), Faktor-faktor terkait kemampuan subkontraktor (VAR4), Faktor-faktor terkait tenaga kerja (VAR5), Faktorfaktor terkait material (VAR7) dan Faktor-faktor terkait kondisi alam (VAR8) sekarang Faktor-faktor terkait kinerja hasil pekerjaan (VAR6) dipengeruhi oleh Faktor-faktor terkait kelengkapan desain (VAR1), Faktor-faktor terkait tenaga kerja (VAR5), dan Faktor-faktor terkait material (VAR7). Sedangkan Faktor-faktor terkait tenaga kerja (VAR5), dipengaruhi oleh Faktor-faktor terkait kemampuan kontraktor (VAR3) dan Faktor-faktor terkait kemampuan kontraktor (VAR3) dipengaruhi oleh Faktor-faktor terkait kemampuan subkontraktor (VAR4), Faktor-faktor terkait klien (VAR2), Faktor-faktor terkait kondisi alam (VAR8), Faktor-faktor terkait material (VAR7) dan Faktor-faktor terkait kondisi hukum, sosial dan ekonomi (VAR9). Selain itu ada perubahan variabel yang menjadi akar permasalahan, yaitu Faktor-faktor terkait kelengkapan desain (VAR1), Faktor-faktor terkait klien (VAR2), Faktor-faktor terkait kemampuan subkontraktor (VAR4), Faktor-faktor terkait kondisi alam (VAR8), dan Faktor-faktor terkait kondisi hukum, sosial dan ekonomi (VAR9) berubah menjadi Faktor-faktor terkait kelengkapan desain (VAR1), Faktor-faktor terkait klien (VAR2), dan Faktor-faktor terkait kondisi alam (VAR8).

Berdasarkan analisis jalur yang telah dilakukan maka diperoleh kedelapan persamaan jalur dengan jalur yang paling dominan memiliki persamaan sebagai berikut:

VAR10 $=0.70$ VAR1 + 0.15 VAR9 + 0.46 VAR3 + 0.20 VAR5 + 0.92 VAR6

\subsection{Diagram jalur berdasarkan nilai proyek yang rata-rata dikerjakan oleh responden}

Berdasarkan hasil responden yang ada, seluruh hasil respon dibagi kedalam 2 kategori berdasarkan nominal proyek yaitu kategori dengan nilai proyek diatas 2 Milyar Rupiah dengan jumlah responden sebanyak 11 responden dan nilai proyek dibawah 2 Milyar Rupiah dengan jumlah responden sebanyak 25 responden. Dari hasil responden yang telah dibagi kedalam 2 kategori maka dilakukan analisis jalur dengan menggunakan LISREL 8.8 diperoleh hasil seperti pada Gambar 4 dan Gambar 5.

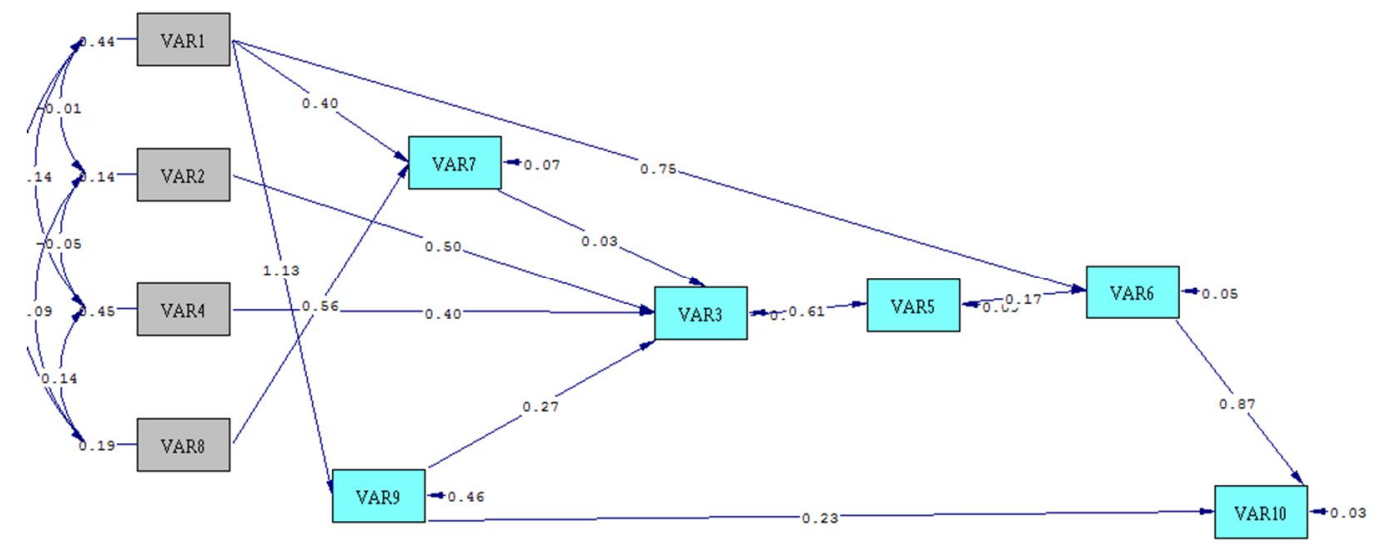

Gambar 4. Diagram jalur dengan nilai proyek diatas 2 Milyar Rupiah 


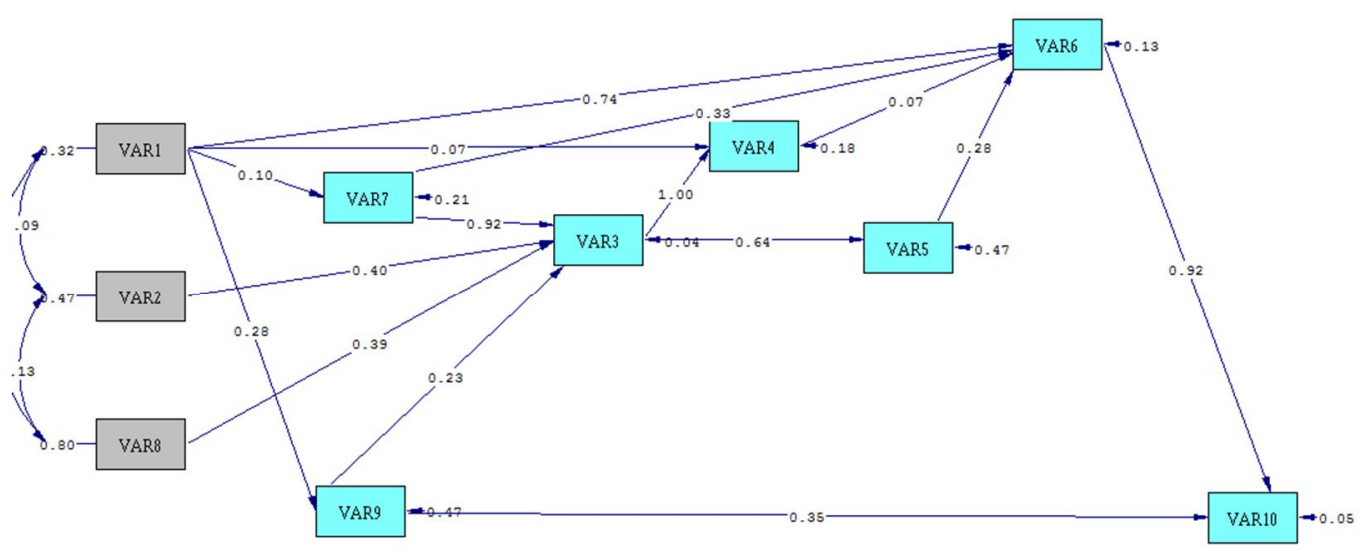

Gambar 5. Diagram jalur dengan nilai proyek dibawah 2 Milyar Rupiah

Dari hasil analisis data untuk kategori proyek di atas 2 milyar diperoleh persamaan jalur faktor-faktor penyebab cost overruns yang dominan adalah:

VAR10 $=0.87$ VAR 6 + 0.17 VAR5 + 0.61 VAR3 + 0.27 VAR9 + 1.13 VAR1

Dari hasil analisis data untuk kategori proyek di bawah 2 milyar diperoleh persamaan jalur faktor-faktor penyebab cost overruns yang dominan adalah:

VAR10 = 0.92 VAR $6+0.28$ VAR5 + 0.64 VAR3 + 0.92 VAR7 + 0.10 VAR1

Hasil penelitian ini memberikan informasi yang berguna untuk meminimalisir terjadinya cost overruns dalam proyek dengan lebih memperhatikan faktor-faktor yang menjadi akar permasalahan terjadinya cost overruns dan faktor-faktor yang memberikan pengaruh dominan. Selain itu pada kontraktor yang hendak mengerjakan proyek rumah dan ruko dapat melihat anggaran proyek yang hendak dikerjakan. Jika nilai proyek berada di angka dibawah dua milyar rupiah, maka faktor-faktor terkait kinerja hasil pekerjaan (VAR6) seperti terjadinya keterlambatan proyek dan rework serta faktor-faktor terkait material (VAR7) seperti ketepatan spesifikasi material yang dibutuhkan dan waktu pengiriman material menjadi perhatian utama yang perlu diperhatikan secara khusus karena memiliki pengaruh yang paling dominan terhadap cost overruns. Sedangkan pada nominal proyek diatas dua milyar rupiah maka faktor-faktor terkait kelengkapan desain (VAR1) menjadi perhatian utama. Hal ini dapat dipahami bahwa dengan nilai proyek yang lebih besar maka umumya memiliki desain proyek dengan kompleksitas yang lebih tinggi sehingga faktorfaktor terkait kelengkapan desain (VAR1) memberi pengaruh yang dominan terhadap terjadinya cost overruns.

\section{KESIMPULAN}

Berdasarkan kajian pustaka dan sinkronisasi terhadap objek penelitian yang fokus pada proyek pembangunan rumah dan ruko di kota Bandung dan Cimahi, diperoleh 9 faktor yang berpotensi menyebabkan terjadinya cost overruns, yaitu: (1) Faktor-faktor terkait kelengkapan desain (VAR1), (2) Faktor-faktor terkait klien (VAR2), (3) Faktor-faktor terkait kemampuan kontraktor (VAR3), (4) Faktor-faktor terkait kemampuan subkontraktor (VAR4), (5) Faktor-faktor terkait tenaga kerja (VAR5), (6) Faktor-faktor terkait kinerja hasil pekerjaan (VAR6), (7) Faktor-faktor terkait material (VAR7), (8) Faktor-faktor terkait kondisi alam (VAR8), (9) Faktor-faktor terkait kondisi hukum sosial dan ekonomi (VAR9). 
Berdasarkan analisis ranking yang dilakukan terhadap 9 faktor yang berpotensi menyebabkan terjadinya cost overruns, terdapat 5 faktor teratas dengan nilai mean di atas 4,00 yakni: faktor terkait kelengkapan desain (VAR1) dengan lingkup yang tidak didefinisikan dengan baik sebagai sub faktor paling dominan, faktor terkait klien (VAR2) dengan masalah keuangan sebagai sub faktor dominannya, faktor terkait kemampuan subkontraktor (VAR4) dengan subkontraktor yang kurang pengalaman sebagai sub faktor paling dominan, faktor terkait kinerja hasil pekerjaan (VAR6) dengan keterlambatan penyelesaian pekerjaan sebagai sub faktor dominannya, dan faktor terkait tenaga kerja (VAR5) dengan ketepatan jumlah komposisi tenaga kerja sebagai sub faktor dominannya

Berdasarkan analisis jalur yang dihasilkan, diperoleh 8 jalur faktor-faktor yang memiliki pengaruh terhadap cost overruns. Dari kedelapan jalur tersebut yang paling dominan adalah: faktor-faktor terkait cost overruns (VAR10) dipengaruhi oleh faktor-faktor terkait kinerja hasil pekerjaan (VAR6), faktor-faktor terkait tenaga kerja (VAR5), faktor-faktor terkait kondisi hukum, sosial dan ekonomi VAR9), faktor-faktor terkait kelengkapan desain (VAR1).

Jalur ini memiliki persamaan:

VAR10 = 0.70 VAR1 + 0.15 VAR9 + 0.46 VAR3 + 0.20 VAR $5+0.92$ VAR 6

Berdasarkan analisis jalur untuk proyek dengan nominal di atas 2 Milyar Rupiah diperoleh 7 jalur yang memiliki pengaruh terhadap cost overrun. Dari ketujuh jalur tersebut yang paling dominan adalah faktor-faktor terkait cost overruns dipengaruhi oleh Faktor-faktor terkait kinerja hasil pekerjaan (VAR6), Faktor-faktor terkait tenaga kerja (VAR5), Faktorfaktor terkait kemampuan kontraktor (VAR3), Faktor-faktor terkait kondisi hukum, sosial dan ekonomi (VAR9), Faktor-faktor terkait kelengkapan desain (VAR1).

Jalur ini memiliki persamaan:

VAR10 = 0.87 VAR 6 + 0.17 VAR5 + 0.61 VAR3 + 0.27 VAR9 + 1.13 VAR1

Berdasarkan analisis jalur untuk proyek dengan nominal di bawah 2 Milyar Rupiah diperoleh 12 jalur yang memiliki pengaruh terhadap cost overruns. Dari kedua belas jalur tersebut paling dominan adalah faktor-faktor terkait cost overruns dipengaruhi oleh Faktorfaktor terkait kinerja hasil pekerjaan (VAR6), Faktor-faktor terkait tenaga kerja (VAR5), Faktor-faktor terkait kemampuan kontraktor (VAR3), Faktor-faktor terkait material (VAR7), Faktor-faktor terkait kelengkapan desain (VAR1)

Jalur ini memiliki persamaan:

VAR10 = 11.37 VAR6 + 2.54 VAR5 + 2.84 VAR3 + 9.76 VAR7 + 0.59 VAR1;

Dari hasil yang telah diperoleh maka dapat disimpulkan bahwa secara umum faktor yang paling berpengaruh terhadap cost overruns adalah faktor-faktor terkait kinerja hasil pekerjaan (VAR6) yang meliputi keterlambatan proyek dan rework. Apabila ditelusuri lebih jauh dengan melihat perbedaan nilai proyek nampak untuk proyek di bawah 2 milyar memiliki faktor dominan yang sama yaitu faktor-faktor terkait kinerja hasil pekerjaan (VAR6) dan faktor-faktor terkait material (VAR7). Sementara untuk proyek di atas 2 milyar faktor yang paling berpengaruh adalah faktor-faktor terkait kelengkapan desain (VAR1). Hal ini dapat dipahami bahwa dengan nilai proyek yang lebih besar maka umumnya memiliki desain proyek dengan kompleksitas yang lebih tinggi sehingga faktor-faktor terkait 
kelengkapan desain (VAR1) memberi pengaruh yang dominan terhadap terjadinya cost overruns.

\section{DAFTAR PUSTAKA}

Azhar, N., Farooqui, R. U., \& Ahmed, S. M. (2008). Cost overrun factors in construction industry of Pakistan. First International Conference on Construction in Developing Countries (ICCIDC-I), Advancing and Integrating Construction Education, Research \& Practice, 499-508.

Chan, A. P. C., Scott, D., \& Chan, A. P. L. (2004). Factors affecting the success of a construction project. Journal of Construction Engineering and Management, 130(1), 153-155.

Doloi, H. (2013). Cost overruns and failure in project management: Understanding the roles of key stakeholders in construction projects. Journal of Construction Engineering and Management, 139(3), 267-279.

Enshassi, A., Al-Najjar, J., \& Kumaraswamy, M. (2009). Delays and cost overruns in the construction projects in the Gaza Strip. Journal of Financial Management of Property and Construction, 14(2), 126-151.

Famiyeh, S., Amoatey, C. T., Adaku, E., \& Agbenohevi, C. S. (2017). Major causes of construction time and cost overruns. Journal of Engineering, Design and Technology.

Febrian, R. (2017). Investigasi faktor penyebab Cost Overruns proyek konstruksi di Indonesia: Perspektif kontraktor. Program Magister Teknik Sipil, Program Pascasarjana Universitas Katolik Parahyangan, Bandung.

Gray, C. F., \& Larson, E. W. (2000). Project Management: The Managerial Process.

Kaming, P. F., Olomolaiye, P. O., Holt, G. D., \& Harris, F. C. (1997). Factors influencing construction time and cost overruns on high-rise projects in Indonesia. Construction Management \& Economics, 15(1), 83-94.

Le-Hoai, L., Dai Lee, Y., \& Lee, J. Y. (2008). Delay and cost overruns in Vietnam large construction projects: A comparison with other selected countries. KSCE Journal of Civil Engineering, 12(6), 367-377.

Memon, A. H., \& Rahman, I. A. (2013). Analysis of cost overrun factors for small scale construction projects in Malaysia using PLS-SEM method. Modern Applied Science, 7(8), 78.

Memon, A. H., Rahman, I. A., \& Aziz, A. A. A. (2012). The cause factors of large project's cost overrun: a survey in the southern part of Peninsular Malaysia. International Journal of Real Estate Studies, 72 (2), 1-15.

Omoregie, A., \& Radford, D. (2006). Infrastructure delays and cost escalation: Causes and effects in Nigeria. Proceeding of Sixth International Postgraduate Research Conference in the Built and Human Environment, 79-93.

Shebob, A., Dawood, N., Shah, R. K., \& Xu, Q. (2012). Comparative study of delay factors in Libyan and the UK construction industry. Engineering, Construction and Architectural Management, $19(6), 688-712$.

Soekiman, A., \& Syamsuduha, S. (2011). The Implementation Effect Of Aspects Relating To Occupational Safety And Health Program Against Productivity In Construction. EACEFInternational Conference of Civil Engineering, 1, 75-82.

Wanjari, S. P., \& Dobariya, G. (2016). Identifying factors causing cost overrun of the construction projects in India. $S \bar{a} d h a n \bar{a}, 41(6), 679-693$.

Westney, R. E. (1997). The Engineer's Cost Handbook: Tools for Managing Project Costs. Marcel Decker. Inc. 